\title{
Work patterns and occupational hazard exposures of North Carolina adolescents in 4-H clubs
}

\author{
Lisa R Cohen, Carol W Runyan, Kathleen A Dunn, Michael D Schulman
}

\begin{abstract}
Objectives-This study documents sex differences in work patterns, injuries, and hazard exposures among adolescents in homes, farms, and other work sites.

Methods-14 to 17 year old 4-H club members were asked to complete self administered questionnaires regarding their lifetime experience of work, hazard exposure, and injuries.
\end{abstract}

Results-Of 323 respondents, more than two thirds had ever worked paid jobs. Fifty seven per cent were injured during non-farm work and hazards were part of the non-farm work environment for $54 \%$ of the respondents. Males were more likely to work in hazardous conditions, including operating heavy equipment on farms or construction sites. Almost three quarters of the teens who worked on farms reported being injured there and $100 \%$ were exposed to at least one farm hazard.

Conclusions-Adolescents perform jobs at homes, farms, or other work sites where they are exposed to numerous safety hazards. Prevention efforts should target specific hazards youths are exposed to rather than the general work site.

(Injury Prevention 1996; 2: 274-277)

University of North Carolina Injury Prevention Research Center and

Department of Health Behavior and Health Education, School of Public Health, Chapel Hill, North Carolina, USA USA

CW Runyan

Department of Emergency Medicine, East Carolina University School of Medicine KA Dunn

Department of Sociology and Anthropology, North Carolina State University MD Schulman

Correspondence and reprint requests to:

Lisa R Cohen, University of North Carolina Injury Prevention Research Center Chase Hall, Campus Bo 7505, Chapel Hill,
27599-7505, USA.
Keywords: adolescents, employment, rural health, North Carolina.

The International Labour Organization, based in Geneva, estimates that more than 200 million children under 14 years of age are employed world wide. ${ }^{1}$ Although approximately $80 \%$ of US adolescents work in after school, summer, or weekend jobs before leaving high school, ${ }^{23}$ little attention has been paid to their working conditions. ${ }^{45}$ More than one half of US 16 and 17 year olds work, many illegally, ${ }^{4}$ although state and federal child labor laws delineate the hours, wages, and types of equipment and jobs permissible for adolescents. ${ }^{6-10}$

Each year in the US more than 30000 adolescents are injured at work. ${ }^{4811}$ Child labor in parts of the world such as the Middle East, India, and South America involves work as rug weavers, miners, and in textiles where disabling injuries are common. ${ }^{1}$ As in other countries, ${ }^{12-14}$ rural areas of the US are likely to contain youths who have paid and unpaid work in agriculture. ${ }^{4}$ Throughout the US adolescents are largely employed in the service sector, in particular fast food establishments, restaurants, grocery stores, and retail sales. ${ }^{4}$

Males are at greater risk for both injury and death than females. ${ }^{115-18}$ Although male and female on-the-job deaths result from different causes, ${ }^{19-21}$ studies have not documented the amount or type of exposure to hazards among working youth, or described exposure differences by sex. ${ }^{8}$

Agricultural work, particularly on family farms, is hazardous and subject to few restrictions. ${ }^{462223}$ It was estimated in 1985 that approximately 300 US youths are killed annually on farms and 23500 suffer serious, non-fatal trauma. ${ }^{24}$

This study was designed to document the patterns of work, exposure to hazards, and injury experiences of youth laboring in households, farms, and non-farm work sites. We selected $4-\mathrm{H}$ club participants to obtain data on youths with either agricultural or non-agricultural jobs.

Founded in 1926, the original mission of 4-H was to improve agricultural production and food preservation. ${ }^{25}$ Although today's mission is broader, ${ }^{26} 4-\mathrm{H}$ maintains a strong rural base. 4-H clubs are locally organized, publicly and privately supported organizations dedicated to the development of young people into productive, responsible citizens. ${ }^{26}$ Public funding comes principally from the US Department of Agriculture and land grant universities, through the state operated Cooperative Extension Services. While North Carolina 4-H reports that 34981 youth participated in $4-\mathrm{H}$ club activities in $1994,{ }^{27}$ it is not known how many were active in local groups during the study period, nor is statewide demographic information available.

\section{Subjects and methods}

Data were collected by self administered questionnaire distributed to all 14 to 17 year old participants at spring 1995 leadership retreats held by all eight North Carolina 4-H districts. District retreats are annual events at which local club members vote on district officers and are provided with training in leadership, work force preparedness, and safety, as well as an opportunity to socialize with their peers. Children from ages 12 through 18 are present, with between 50 and 75 teens aged 14 to 17 years attending each two day retreat.

Approximately one month before each retreat, parents of all local club members were given a consent form by their local club leader. Parents were asked to sign and return the form only if they did not wish their child to fill out the Teen Work survey. Parents were also 
provided with a toll free telephone number to call with questions about the study.

'Non-farm work' was defined as employment for pay, regardless of amount of payment, regularity of work, or relationship to employer. Babysitting and chores were included if payment was received. Farm work was defined as any paid or unpaid tasks or chores directly related to crop or livestock production. Because respondents may have worked in non-farm settings only, farm settings only, or both, the 'non-farm' group and the 'farm' group are overlapping.

Except for three questions assessing work during the past summer or school year, question phrasing was 'Have you ever ....' with yes or no response options. While this type of question allows us to document the prevalence of types of work, exposure to hazards, and types of injuries received while working, it does not allow us to link specific jobs to specific hazards or to specific injuries.

\section{Results}

Only two parents called the toll free telephone number with questions about the study. Both agreed to allow their child to complete the questionnaire. No parents refused to allow their child to participate.

A total of 343 questionnaires were returned, of which 323 usable questionnaires were obtained. Fourteen questionnaires were removed because the respondents were not

Table 1 Places worked for pay, by sex, 4- $H$ respondents

\begin{tabular}{|c|c|c|c|}
\hline Places worked & $\begin{array}{l}\text { Female }\left({ }^{\circ}\right) \\
(n=210)\end{array}$ & $\begin{array}{l}\text { Male }(\%) \\
(n=112)\end{array}$ & p Value \\
\hline Home & 78 & 68 & 0.063 \\
\hline Farm & 24 & 39 & 0.006 \\
\hline Store (not food or convenience store) & 13 & 6 & 0.056 \\
\hline Camp, park, or swimming pool & 12 & 8 & 0.310 \\
\hline Building or construction site & 4 & 20 & 0.001 \\
\hline Day care center & 11 & 4 & 0.019 \\
\hline Fast food retaurant & 6 & 9 & 0.262 \\
\hline Another kind of restaurant (not fast food) & 9 & 8 & 0.896 \\
\hline Supermarket or grocery store & 6 & 5 & 0.651 \\
\hline Nursing home or hospital & 4 & 2 & $0 \cdot 328$ \\
\hline Gas station or garage & 1 & 5 & 0.091 \\
\hline Convenience store that sells gas and food & 1 & 5 & 0.038 \\
\hline Factory or mill & 0 & 4 & 0.031 \\
\hline Movie theater & 0 & 2 & 0.051 \\
\hline Some other kind of business placet & 20 & 23 & 0.571 \\
\hline
\end{tabular}

*p Values below 0.05 are shown in bold face type.

tOpen ended responses to this item indicated a variety of small businesses including offices, schools, greenhouses, and health related businesses.

Table 2 Types of injuries, by work environment and sex, 4- $H$ respondents

\begin{tabular}{|c|c|c|c|c|c|c|}
\hline \multirow[b]{2}{*}{ Injury types } & \multicolumn{3}{|c|}{ Non-farm $(n=322)$} & \multicolumn{3}{|c|}{ Farm $(n=111)$} \\
\hline & $\begin{array}{l}\text { Female } \\
\left(\begin{array}{c}0 \\
0\end{array}\right)\end{array}$ & $\begin{array}{l}\text { Male } \\
\left(\begin{array}{c}0 \\
0\end{array}\right)\end{array}$ & p Value & $\begin{array}{l}\text { Female } \\
(\%)\end{array}$ & $\begin{array}{l}\text { Male } \\
(\%)\end{array}$ & p Value \\
\hline Lifted something heavy & 34 & 41 & $0 \cdot 230$ & 31 & 42 & $0 \cdot 295$ \\
\hline Cut by something sharp & 30 & 44 & $0 \cdot 016$ & 41 & 64 & 0.028 \\
\hline Fell down, tripped, or slipped & 30 & 28 & $0 \cdot 752$ & 50 & 32 & 0.082 \\
\hline Hit, kicked, or bitten by someone & 25 & 16 & 0.063 & - & - & - \\
\hline Burned & 17 & 25 & 0.063 & 16 & 33 & 0.037 \\
\hline Something fell on you & 11 & 21 & 0.018 & 17 & 19 & $0 \cdot 770$ \\
\hline Hit, kicked, or bitten by animal & 8 & 17 & 0.014 & 37 & 36 & 0.917 \\
\hline Car or truck crash & 3 & 8 & 0.032 & 4 & 11 & $0 \cdot 180$ \\
\hline Caught in machinery & 1 & 7 & 0.006 & 7 & 17 & $0 \cdot 128$ \\
\hline Hit by car, truck, or equipment & 1 & 6 & 0.016 & 3 & 14 & 0.030 \\
\hline Shot by gun & 0 & 7 & 0.001 & 0 & 6 & 0.046 \\
\hline Sickened from handling tobacco & - & - & - & 7 & 11 & 0.488 \\
\hline Sick from pesticide or chemical & - & - & - & 3 & 11 & 0.082 \\
\hline Having a tractor rollover & - & - & - & 0 & 6 & 0.046 \\
\hline
\end{tabular}

*p Values below 0.05 are shown in bold face type. between 14 and 17 years of age and six were removed because the respondents claimed not to be members of 4-H. District leaders, who distributed and collected the questionnaires, reported no refusals to complete the questionnaires. Because 4- $\mathrm{H}$ does not keep a roster of club members, it was not possible to examine differences between respondents and the overall $4-\mathrm{H}$ population.

The 323 respondents were mostly female $(65 \%)$ and white $(65 \%)$ and represented 74 of North Carolina's 100 counties. Twenty per cent lived on farms.

\section{NON-FARM PAID JOBS}

Work characteristics

Most respondents were paid to babysit for people other than their own siblings $(70 \%)$, did chores around the house $(69 \%)$, or worked at other paid jobs for family members $(68 \%)$. Three quarters worked for people outside their families and of these, $27 \%$ had their first paid job before age 13.

Many teens worked at night. Excluding babysitting, 30\% worked between $9 \mathrm{pm}$ and midnight and $12 \%$ worked between midnight and $7 \mathrm{am}$. Males were significantly more likely than females to work between $9 \mathrm{pm}$ and midnight $(37 \% v 26 \%, \mathrm{p}=0.039)$ and between midnight and $7 \mathrm{am}(17 \% v 9 \%, \mathrm{p}=0.023)$. There was no relationship between age and night-time work.

Although both males and females were most likely to work at home or on a farm, work places and jobs also differed by sex. Males were more likely than females to work on farms, building or construction sites, convenience stores, and factories or mills (table 1 ).

\section{Injury experience}

Fifty seven per cent of respondents reported being injured while working for pay; $17(5 \%)$ either missed school or work for at least one day and/or visited a doctor, nurse, or hospital due to the injury. Twelve per cent of males compared with $3 \%$ of females sought medical care for their injuries $(p=0.004)$. While a greater proportion of males $(11 \%)$ than females $(6 \%)$ missed school or work due to an injury, this difference was not statistically significant $(\mathrm{p}=0 \cdot 248)$

We provided respondents with a list of injury events and asked if they had 'ever been hurt while working' in any of these ways. The most common means of injury were: lifting something heavy $(37 \%)$; being cut by something sharp (35\%); and falling down, tripping, or slipping $(30 \%)$ (table 2). While males and females were equally likely to be injured while lifting something heavy or as the result of a fall or slip, males were significantly more likely to be cut.

\section{Hazard exposure}

Hazards were part of the work environment for $54 \%$ of all respondents, although males were significantly more likely than females to report 
exposure to multiple hazards. When provided with a list of hazards, at least $30 \%$ of male teens indicated work exposure to one or more of the following: outdoor bodies of water; very loud noises; a car or truck; ladders or scaffolding; gasoline; or drills or chain saws.

\section{FARM WORK}

Work characteristics

One hundred and twelve respondents reported working on a farm. Of these, $61 \%$ worked on only one farm; $21 \%$ on three or more farms. Most $(69 \%)$ worked on a relative's farm and $84 \%$ reported being paid for farm work.

Teens reported more farm work during the summer than the school year. In the summer, $32 \%$ worked more than four hours per day compared with $11 \%$ during the school year. Forty nine per cent of the males and $24 \%$ of the females worked more than four hours on an average summer day.

Notably, $62 \%$ of the respondents reported at least sometimes feeling rushed to get their farm work done on time. Of these, 39\% reported often or always feeling rushed. There were no sex differences.

\section{Injury experience}

Almost three quarters $(71 \%)$ of the teens who worked on farms reported being injured there (table 2). Respondents were most likely to have: been cut by something sharp; fallen down, tripped, or slipped; or been hit, kicked, or bitten by an animal. Ten (9\%) either missed at least one day of work or school and/or received medical treatment due to an injury sustained on the farm. As with non-farm injuries, males were more likely to be cut by something sharp than were females. In addition, males were significantly more likely than females to have been burned while working on a farm.

\section{Hazard exposure}

All respondents reported exposure to at least one farm hazard on the list presented and $52 \%$ were exposed to at least 10 hazards. The most common hazards were riding or driving trac-

Table 3 Exposure to farm environment hazards, by sex, 4- $H$ respondents

\begin{tabular}{|c|c|c|c|}
\hline Hazards & $\begin{array}{l}\text { Female }(\%) \\
(n=72)\end{array}$ & $\begin{array}{l}\text { Male }(\%) \\
(n=39)\end{array}$ & $p$ Value \\
\hline $\begin{array}{l}\text { Ridden on a tractor } \\
\text { Handled or fed large animals } \\
\text { Used a BB gun or air gun } \\
\text { Driven a tractor } \\
\text { Loaded farm equipment or goods } \\
\text { Used a rifle or shotgun } \\
\text { Driven a farm truck } \\
\text { Ridden on an all terrain vehicle } \\
\text { Used a handgun } \\
\text { Used pesticides or other farm chemicals } \\
\text { Used a bushhog or rotary mower } \\
\text { Use a chain saw } \\
\text { Used a power take off device } \\
\text { Worked or played in a grain bin } \\
\text { Barned or primed tobacco } \\
\text { Picked tobacco by hand } \\
\text { Used an auger } \\
\text { Used a combine } \\
\text { Used a tobacco harvester }\end{array}$ & $\begin{array}{l}83 \\
83 \\
64 \\
69 \\
67 \\
46 \\
49 \\
42 \\
29 \\
29 \\
27 \\
18 \\
20 \\
29 \\
29 \\
25 \\
11 \\
14 \\
15\end{array}$ & $\begin{array}{l}90 \\
76 \\
95 \\
80 \\
77 \\
80 \\
62 \\
64 \\
64 \\
59 \\
62 \\
64 \\
56 \\
33 \\
33 \\
31 \\
32 \\
26 \\
18\end{array}$ & $\begin{array}{l}0 \cdot 359 \\
0 \cdot 373 \\
0 \cdot 001 \\
0 \cdot 238 \\
0 \cdot 259 \\
0 \cdot 001 \\
0 \cdot 193 \\
0 \cdot 024 \\
0 \cdot 001 \\
0 \cdot 002 \\
0 \cdot 001 \\
0 \cdot 001 \\
0 \cdot 001 \\
0 \cdot 649 \\
0 \cdot 649 \\
0 \cdot 542 \\
0 \cdot 007 \\
0 \cdot 124 \\
0 \cdot 716\end{array}$ \\
\hline
\end{tabular}

${ }^{\star} \mathrm{p}$ Values below 0.05 are shown in bold face type. tors; handling or feeding large animals; using BB guns or air guns; and loading farm equipment or goods (table 3 )

Because tractors are a common farm hazard, ${ }^{23,28-31}$ we asked about them specifically. Fifty per cent of the respondents drove a tractor without rollover protection; $64 \%$ drove without using a seat belt; and $59 \%$ had driven with a passenger. Males were more likely to have engaged in each named hazardous practice than were females.

\section{Training}

Few respondents reported having had any safety training. Of the 85 teens who worked with large animals, $59 \%$ had received related training. Forty three respondents had used pesticides or other farm chemicals, but only 16 $(37 \%)$ had received pesticide or chemical training. Similarly, only $35 \%$ of the 77 teens who had driven a tractor had received training in tractor operation.

\section{Discussion}

North Carolina children start working at a young age and do various jobs at home, on farms, and at other work sites where they are exposed to numerous safety hazards. Youth labor is complex, including paid and unpaid activities in each of these settings, activities often not considered to be within the formal labor market or studied in occupational injury research. Our results also show a division of labor by sex in each setting. This interaction of sex and work environment creates a complicated pattern of teen work.

More than half of our respondents reported being injured while working non-farm jobs and more than $70 \%$ of farm workers were injured. However, as in other adolescent work studies, ${ }^{151831}$ fewer than $10 \%$ missed work or school or sought medical attention for their injuries. It is unclear whether our respondents reported numerous minor injury events or neglected to seek care for potentially serious injuries.

Study participants who worked on farms reported receiving little training and often felt rushed to complete their jobs. Compounding these problems, they are exposed to farm hazards ranging from pesticides to driving tractors without rollover protection to handling large animals.

Although this study improves our understanding of the jobs adolescents do and the hazards and injuries they encounter at work, there are limits to its generalizability. The 4-H teens were mostly young, female, and more likely to be African-American than the state population, presumably a function of $4-\mathrm{H}$ membership. Also, we did not link specific hazards to specific jobs in an effort to keep the survey questions simple.

Data collected through self administered questionnaires are subject to problems with literacy, attention span, and ability to comprehend time frames. Future studies should use interview methods that allow response 
confirmation and permit linking specific jobs to specific hazard exposures and injury events.

\section{Implications for prevention}

Because teens work at many different jobs, both over time and concurrently, injury prevention programs must be multifaceted. Job specific worker education may not be appropriate. In addition, although males and females may be working at the same job sites, they are exposed to different hazards at work. Therefore, future prevention programs should take into account job specific tasks and exposures.

Most home safety programs address hazards faced by young children. Our results show that babysitting and lawn care are common jobs of teens in home environments. Therefore, home safety programs should be expanded to address hazards faced by teens working in and around the home.

Many of our respondents worked on farms and all were exposed to at least one hazard on the farm. Though training programs are available for operating tractors, using pesticides, and handling large animals, few respondents have taken advantage of these training opportunities. The need for training before undertaking potentially dangerous tasks should be emphasized. In addition, injury prevention practitioners should strive to strengthen legislation to protect children working on farms.

Unfortunately, the link between hazard exposures and injuries is still unknown. Future research should attempt to estimate exposure time for specific hazards so that rates of injury by time exposed can be calculated.

This research was supported by grant R49/CCR402444-10 from the Centers for Disease Control and Prevention, Atlanta, Georgia, to the Injury Prevention Research Center, University of North Carolina, Chapel Hill. Additional support was received from the North Carolina Agricultural Research Service.

The authors acknowledge Michael Davis, $\mathrm{PhD}$, and Candace Goode, $\mathrm{PhD}$, at the North Carolina Cooperative Extension Service, Department of 4-H Youth Development, for providing data on $4-\mathrm{H}$ and access to the 4-H participants, and all the extension agents from throughout North Carolina who made this study possible. We would also like to thank Diane Calleson, MS, for her assistance in planning and implementing this project.

1 Landrigan PJ, Pollack SH, Belville R, Godbold JG. Child labor in the United States: historical background and current crisis. Mt Sinai $\mathcal{f}$ Med 1992; 59: 498-503.

2 Parker DL, Carl WR, French LR, Martin FB. Nature and incidence of self-reported adolescent work injury in Minnesota. Am ₹ Ind Med 1994; 26: 529-41.
3 Greenberger E, Steinberg L. When teenagers work: the psychological and social costs of adolescent employment. New York: Basic Books, 1986.

4 Landrigan PJ, Pollack SH, Godbold JH, Belville R. Occupational injuries: epidemiology, prevention, treatment. tional injuries: epidemiology, prevention, treatment. Adolescent
207-14.

5 Runyan CW, Gerken EA. Epidemiology and prevention of adolescent injury: a review and research agenda. $\mathcal{F} A M A$ 1989; 262: 2273-9.

6 Department of Labor. Federal child labor laws in farm jobs. Washington, DC: US Department of Labor, 1990.

7 Department of Labor. Federal child labor laws in nonfarm jobs. Washington, DC: US Department of Labor, 1990.

8 Pollack SH, Landrigan PJ, Mallino DL. Child labor in 1990: prevalence and health hazards. Annu Rev Public Health 1990; 11: 359-75.

9 Beyer D. Current trends in state child labor legislation and enforcement. Am ₹ Ind Med 1993; 24: 347-50.

10 Department of Labor. Child labor requirements in nonagricultural occupations under the fair labor standards act. Child labor bulletin No 101. Washington, DC: US Government labor bulletin No 101 . Wrinting Office, 1985.

11 Layne LA, Castillo DN, Stout N, Cutlip P. Adolescent occupational injuries requiring hospital emergency department treatment: a nationally representative sample. Am F Public Health 1994; 84: 657-60.

12 Doyle Y, Conroy R. Childhood farm accidents: a continuing cause of concern. Fournal of the Society for Occupational Medicine 1989; 39: 35-7.

13 Jacobbson B, Schelp L. One-year incidents of occupational injuries among teenagers in a Swedish rural municipality. Scand 7 Soc Med 1988; 16: 21-5.

14 Clarke J, Marshall S, Langley J, Cryer C. Epidemiology of injuries occurring on New Zealand farms: a report to the injuries occurring on New Zealand farms: a report to the tion. Dunedin, NZ: University of Otago Injury Prevention. Dunedin, NZ: Universit

15 Banco L, Lapidus G, Braddock M. Work-related injury among Connecticut minors. Pediatrics 1992; 89: 957-60.

16 Dunn KA, Runyan CW. Deaths at work among children and adolescents. Am f Dis Child 1993; 147: 1044-7.

17 Belville R, Pollack SH, Godbold JH, Landrigan PJ. Occupational injuries among working adolescents in New York State. FAMA 1993; 269: 2754-9.

18 Brooks DR, Davis LK, Gallagher SS. Work-related injuries among Massachusetts children: a study based on emergency department data. Am 7 Ind Med 1993; 24: 313-24.

19 Division of Safety Research, NIOSH. Traumatic occupational fatalities - United States, 1980-1984. MMWR Morb Mortal Wkly Rep 1987; 36: 461-4, 469-70.

20 Jenkins EL. Occupational injury deaths among females: the US experience for the decade 1980 to 1989 . Ann Epidemiol US experience for th

21 Castillo DN, Landen DD, Layne LA. Occupational injury deaths of 16 and 17-year olds in the United States. $A m \mathcal{F}$ Public Health 1994; 84: 646-9.

22 Wilk VA. Health hazards to children in agriculture. $A m \mathcal{f}$ Ind Med 1993; 24: 283-90.

23 Purschwitz MA, Field WE. Scope and magnitude of injuries in the agricultural workplace. $A m \mathcal{F}$ Ind Med 1990; 18: $179-92$.

24 Rivara FP. Fatal and nonfatal farm injuries to children and adolescents in the United States. Pediatrics 1985; 76: 567-73.

25 Clark JW. Clover all over: North Carolina State 4- $H$ in action. Raleigh, NC: Office of 4-H and Youth, North action. Raleigh, NC: Office of

26 Wessel T, Wessel M. 4-H: an American idea, 1900-1980. Chevy Chase, MD: National 4-H Council, 1982.

27 North Carolina Cooperative Extension Service. North Carolina 4-H: growing to meet the needs of today's youth. Raleigh, NC: North Carolina State University, 1995.

28 Bernhardt J, Langley RL. Agricultural hazards in North Carolina. NC Med f 1993; 54: 512-5.

29 Bernhardt JH, Langley RL. Accidental occupational farm fatalities in North Carolina: 1984 to 1988. Fournal of Rura Health 1992; 8: 60-9.

30 Cogbill TH, Busch HM Jr, Stiers GR. Farm accidents in children. Pediatrics 1985; 76: 562-6.

31 Anonymous. Farm-tractor-related fatalities - Kentucky, 1994. MMWR Morb Mortal Wkly Rep 1995; 44: 481-4. 